症例

肝細胞腺腫との鑑別を要した多血性高分化型小肝細胞癌の 1 例

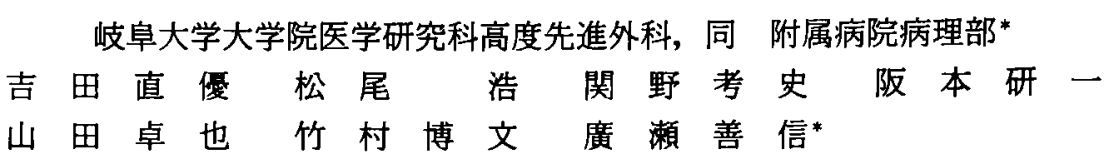

症例は78歳, 男性. 既往歴として肝細胞癌で肝 S5切除術を受けていた。残肝 S4にCT と血管造影で造影早期から平衡相まで濃染する $1.5 \mathrm{~cm}$ 大の腫場を認められた. 肝細胞癌 の再発を疑ったが, 高分化型の小肝細胞癌としては早期から均一な濃染像を示したため, 鑑別疾患として肝細胞腺腫の可能性も考え，肝 S4部分切除術を施行した。腫演は肉眼的 に境界明瞭で均一な白色調であり, 病理組織学的に淡明で異型性の低い腫場細胞が, 敷 石状に増殖していた，病理組織学的にも肝細胞腺腫との鋁別が困難であったが, 細胞が 小型化し核が巨大化し，核胞体比が増大していること，索状構造が細索状でなく分厚い こと, 細胞密度が高いことから, 高分化型肝細胞癌と考えられた，高分化型小肝細胞癌 は濃染しないことが多いが，小型であっても多血性の画像所見を呈する場合があり，念 頭に置くべきでると考えられた。

真引用語：腫場濃染, 肝細胞腺腫, 高分化型肝細胞癌

緒 言

肝細胞癌 (hepatocellular carcinoma, 以下 HCC) と鑑別を要する多血性の腫癌には肝細胞腺腫（liver cell adenoma, 以下 LCA) と限局性再生性過形成 (focal nodular hyperplasia, 以下 FNH) がある. LCA と高分化型 HCC は, 病理組織学的にも鑑別が困 難といわれるいー6). またCTや血管造影で典型的な HCC は襄染するが, 高分化て小型の HCC は濃染しな いことが多い7). 今回, LCA との鑑別が困難であった 高分化型 HCC の 1 例を経験したので報告する.

$$
\text { 症例 }
$$

患者：78葴, 男性.

主訴：特になし.

家族歴：特記すべきことなし.

既往歴：38歳時に急性腹症て緊急手術を受けた（詳 細不明, 輸血あり). 72歳時に HCC に対し, 肝 S5切除 術を施行された。この時に術前の腫場マーカーはCEA が7.0ng/ml, AFP が90.6ng/ml, PIVKA-II が956.0 $\mathrm{mAU} / \mathrm{ml}$ と上昇していたが,術後にすべて正常となった。

2004年12月 7 日受付 2005 年 3 月11日採用

〈所属施設住所〉

テ501-1194 岐阜市柳戸 $1-1$
現病歴：上記手術後,近医で経過観察をされていた。 2004年 2 月に腹部 CT で残肝 S4に腫場を認められた.

入院時現症: 身長 $170 \mathrm{~cm}$, 体重 $66 \mathrm{~kg}$. 腹部は平坦. 軟で, 上腹部に手術痗痕を認めた。

入院時検查所見 : RBC $386 \times 10^{4} / \mathrm{mm}^{3}, \mathrm{Hb} 10.2 \mathrm{~g} /$ dl と軽度の貧血を認めた. HBs 抗原陽性, HCV 抗体 陰性で, 肝機能は正常であった。腫痬マーカーはCEA, CA19-9, AFP が正常で, PIVKA-IIが108.8mAU/ml と上昇していた.

初回手術所見：肝 S5の腫瘍は大きさ $6.0 \times 5.0 \mathrm{~cm}$, 单純結節型で, 被膜と隔壁を持ち, 内部が所々髙死し ていた。病理組織学的に厚い索状構造をとった充実性 の腫場が不規則に配列し增殖しており,中分化型 HCC であった(H1, St-A, eg, fc(+), fc-inf(+), sf(+), s0, n0, vp0, vv0, va0, b0, im0, p0, sm(-), CH, $\mathrm{t} 2, \mathrm{n} 0, \mathrm{~m} 0$, stage II) (図 1 ).

腹部超音波所見：肝 $\mathrm{S} 4$ の表面に大きさ $15 \times 10 \mathrm{~mm}$ の内部低輝度で均一な腫瘍を認めた。腫瘍の背側に 5 $\mathrm{mm}$ 大の毫胞があった（図 2 ）。

腹部 CT 所見：腫場は単純で周囲肝実質より高吸収 域であった，造影で腫場は動脈相早期から全体が均一 に濃染し，平衡相まで淡く造影された（図3)。

腹部 MRI 所見 : 腫瘍は T1強調像で周囲肝実質と 


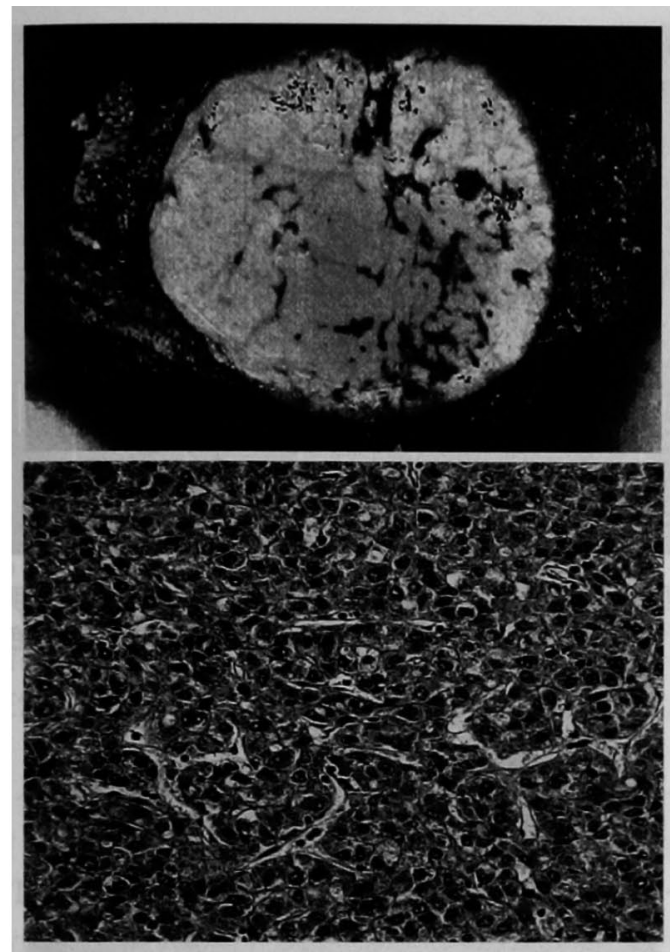

园 1 初回手術所見：肝 S5の腫暍は大きさ6.0 65.0 $\mathrm{cm}$, 単純結節型で, 被膜と隔壁を持ち, 内部が所々 壊死していた(图 $1 \mathrm{~A}$ ). 病理組織学的に分厚い索状 構造をとった充実性の腫瘍が不規則に配列し增殖 しており，中分化型肝細胞蕰であった(図 1 B , HE 染色, $\times 100$ ).

$\frac{\mathrm{A}}{\mathrm{B}}$

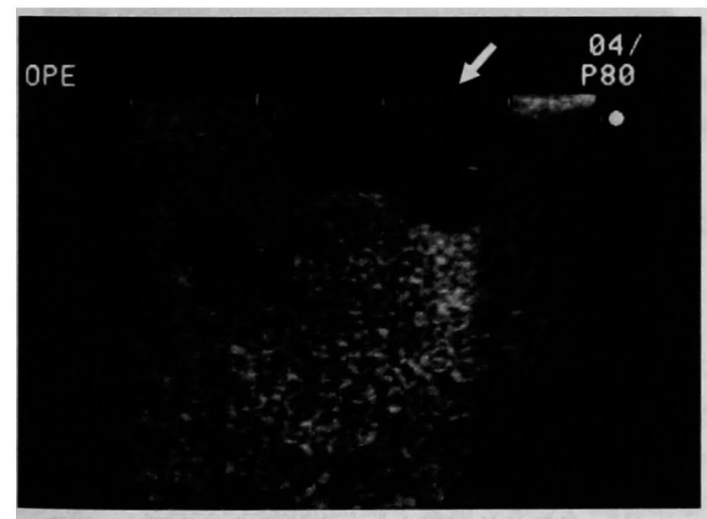

図 2 腹部超音波所見：肝 S4の表面に大きさ $15 \times 10 \mathrm{~mm}$ の内部低煇度で均一な腫堭を認めた（矢印）。

等信号域に，T2強調像で谈い高信号域に描出され，背 側の毫胞はより高信号であった．ガドリニウム造影て 腫㷎は造影直後から浂染した（図4）。

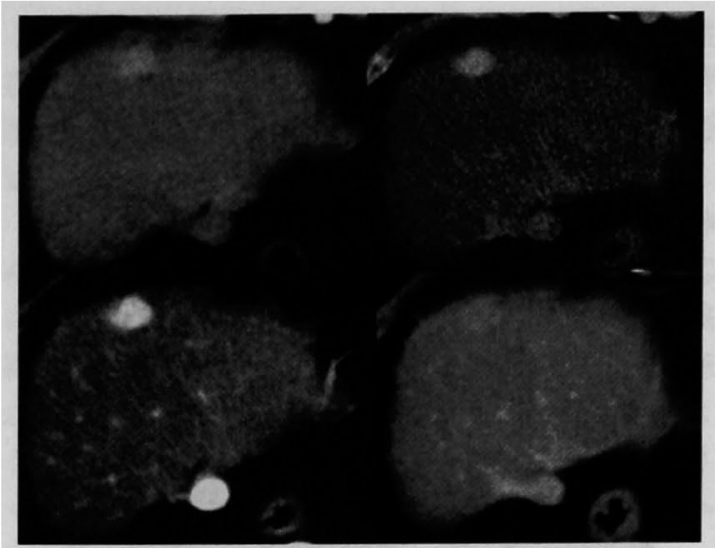

図 3 腹部 CT 所見：腫疸は単純で周囲肝実質より高吸 収域であった(図 $3 \mathbf{A}$ )。造影で腫瘍は動脈相（図 $3 \mathbf{B}$ ： 早期, 図 $3 \mathrm{C}$ : 後期) から全体か均一に浱染し, 平衡相 （図３Ｄ）まで淡く造影された。 \begin{tabular}{l|l}
$\mathrm{A}$ & $\mathrm{B}$ \\
\hline $\mathrm{C}$ & $\mathrm{D}$
\end{tabular}

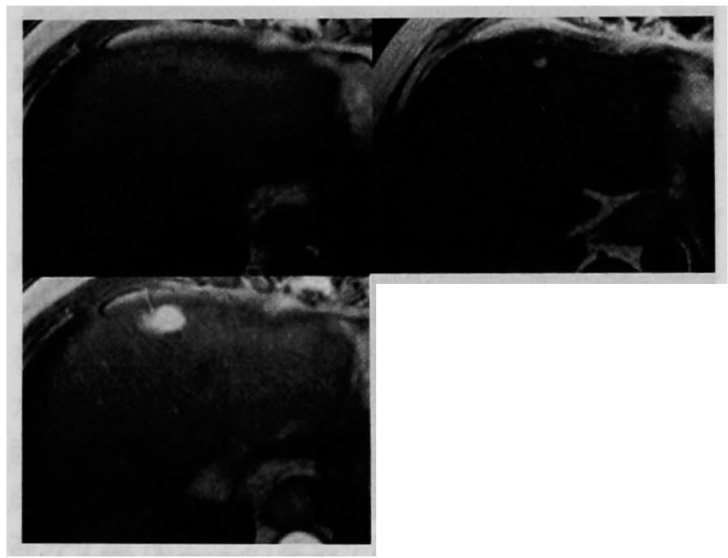

図4 腹部 MRI 所見：畽疸は T1強調像 (図 4A) で周囲 肝実質と等信号域に, T2強調像 (図 4 B ) で淡い高信号 域に描出され，背側の蕉胞はより高信号であった，Gd

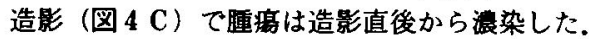

$$
\begin{array}{l|l}
\mathrm{A} & \mathrm{B} \\
\hline \mathrm{C} &
\end{array}
$$

血管造影所見：肝動脈枝 A4の末梢に腫場濃染を認 めた。腫瘍内の血管の届曲や蛇行は明らかでなかった (図 5 ).

肝動脈造影下 CT 所見：腫瘍は辺緑と中心がほほ同 時に極めて強く濃染した。造影剂が周囲の肝実質に広 がりつつ，腫湯濃染が持続した，経動脈性門脈造影下 CTて腫場の部位に一致して, 門脈血流欠損域を認め た (図6).

術前に HCC の再発と診断したが, 画像上, 腫痬は早 


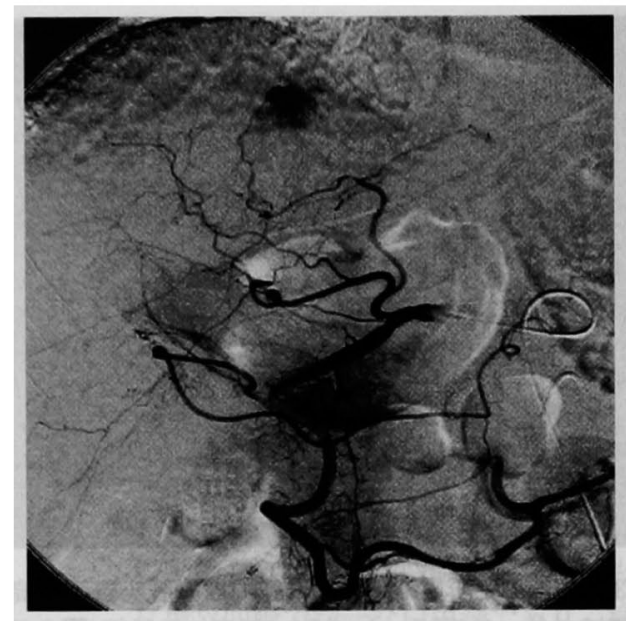

図 5 血管造影所見：肝動脈枝 A4の末梢に腫㾨 濃染を認めた。腫瘍内の血管の届曲や蛇行は明 らかでなかった。

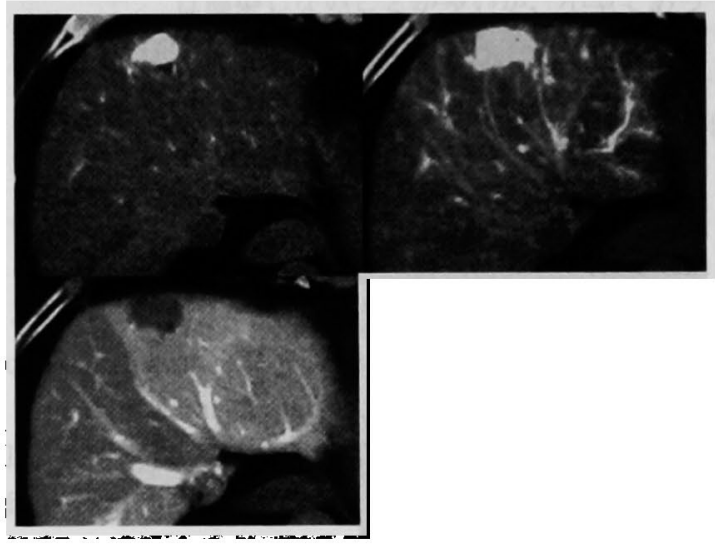

図6 肝動脈造影下 CT 所見：腫㾇は造影直後（図 $6 \mathrm{~A}$ ) から辺縁と中心がほぼ同時に極めて強く涱染し, 20秒後 (図 6 B ) に造影剠が周囲の肝実質に広がり腫癔䈨染が 持続した。経動脈性門脈造影下 CT (図 6 C) で腫瘍の 部位に一致して, 門脈血流欠損域を認めた。 $\quad \frac{\mathrm{A}}{\mathrm{C}} \mid \mathrm{B}$

期から濃染したため, 鑑別疾患として LCA の可能性 も考えた。2004年 3 月 2 日に手術を施行した.

手術所見：肝臓は表面平滑で光沢もあり，慢性肝炎 と考えられた. 腫瘍は S4の表面に露出していた. 肝 S4 部分切除術を施行した。

切除標本所見：腫瘍は大きさ $1.4 \times 1.2 \mathrm{~cm}$ て, 境界 明膫で辺縁整な単純結節型であった。内部に出血や壤 死はなく, 光沢に富んだ均一な白色調の腫瘍であった。 腫瘍の背側に小素胞を認めた（図 7 ).

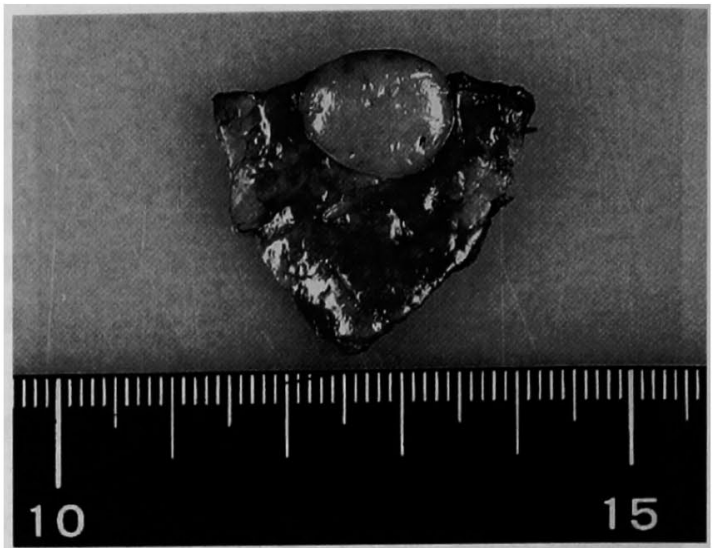

图 7 切除樈本所見：腫痬は大きさ $1.4 \times 1.2 \mathrm{~cm}$, 境界明 瞭で辺縁整な単純結節型で, 光沢に富んだ均一な白色 調であった。

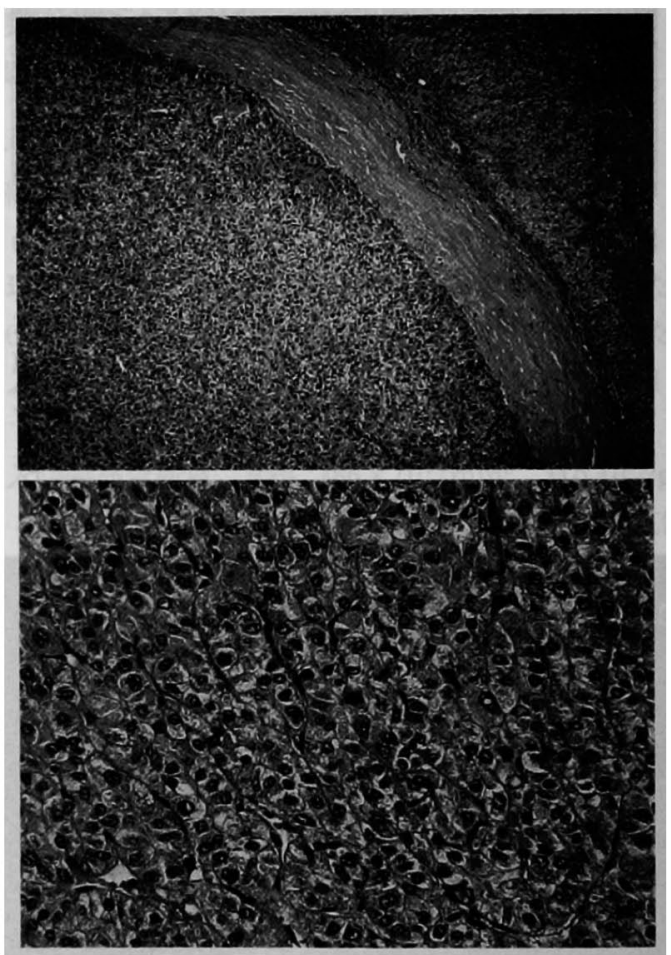

図 8 病理組織学的所見：腫㾰は線維性の被膜を持 ち, 䁗張性に発育していた（図 $8 \mathrm{~A}, \mathrm{HE}$ 染色, $\times$ 40). 核胞体比が増大し, 索状構造が分厚く, 細胞 密度が増加していた（図 8 B, HE 染色, $\times 100$ ). 
病理組織学的所見：腫瘍は線維性の被膜を持ち, 㜆 張性に発育していた，水様透明で明るい胞体を持った 淡明な腫㾤細胞が,単調均一に数石状に增殖していた。 当初, LCA との鑑別が問題となったが, 複数の病理医 に高診し再検討したところ, 腫痬は初回手術時の腫瘍 と同様に，細胞が小型化し核が巨大化し，核胞体比が 増大していること, 索状䅇造が細索状でなく分厚いこ と，細胞密度が高いことから，脂肪化を伴った高分化 型 HCC と診断した(図 8 ). H1, St-M, $1.4 \mathrm{~cm}, \mathrm{eg}$, $\mathrm{fc}(+), \mathrm{fc}-\inf (-), \mathrm{sf}(-), \mathrm{s} 0, \mathrm{n} 0, \mathrm{vp} 0, \mathrm{vv0}$, va0, b0, $\operatorname{im} 0, \mathrm{p} 0, \mathrm{sm}(-), \mathrm{CH}, \mathrm{t} 1, \mathrm{n} 0, \mathrm{~m} 0$, stage I $\succ$ あった。

術後経過：経過良好で，術後第11病日に退院した。 術後に腫瘍マーカーの PIVKA-II は17.0mAU/ml と 正常となった。術後10力月の現在, 無再発生存中である.

\section{考察}

一般に腫瘍径の小さい高分化型 $\mathrm{HCC}$ は，周囲肝実 䝯との境界が不明瞭であり，血流も少ないため，造影 CTの早期相で等から低吸収域に，血管造影で hypovascularに描出される ${ }^{6 / 8)}$. 斎藤ら ${ }^{9}$ は高分化型 HCC の55症例60結節の血管造影所見を検討し,全体が 濃染された結節はなく，一部が浀染された結節が 7 結 節 (12\%)，濃染されなかった結節が53結節 $(88 \%)$ て あった。その理由は，腫場内に門脈域が存在し，門脈 血流によって栄養されていること，被膜がなく造影剤 が流れやすいこと，腫瘍が非癌部に比べて構造異型に そしいことなどが考えられる1011)，分化度が低くなる につれて動脈血流が有意になり，構造異型が進み，濃 染されるようになる ${ }^{12)}$. 本症例は腫瘍径が $1.4 \times 1.2 \mathrm{~cm}$ と小型であったが，CT と血管造影で早期から全体が 均一に湦染し，平衡相においても残存がみられた。 HCC の術後であり，HCCの再発を強く疑ったが，画 像所見上その他の多血性腫瘍も否定できなかった。

HCC と鑑別を要する多血性の腫瘍にはLCA と FNH が挙げられる.LCA は若年の女性に多く，欧米 では経口避妊楽やステロイドホルモンとの関連が指摘 されているが，本邦ではそれらの薬剤に関連した報告 は少ない ${ }^{13)}$. LCA は動脈血流が豊富であり，血管造影 で腫煌の辺縁から中心に向かう規則的な求心性の血管 走行を特徵とする13144．腫場の内部に出血や壊死を認 めることが多い. LCA は悪性化例を除いて腫瘍マーカ 一は正常であるが, PIVKA-II高值を示したLCA の 報告例もみられる ${ }^{13)}$. FNH は血管造影で腫瘍の中心 から辺緑の線維性隔壁に向かう車軸様の血管走行 (spoke-wheel pattern) を特徵とし，腫瘍の中心に星 芒状の線維性㗪痕を認める ${ }^{15}$. 本症例は車軸様の血管 走行や中心性痴痕を疑わせる所見はなく，FNH は否 定的であった。

HCC と LCA はともに求心性の血行動態を示す. 林 ら ${ }^{16)}$ は HCC と LCA の血管造影所見について, HCC は太い栄責動脈からの分枝の走行が屈曲や蛇行し不規 則て，管径の広狭不整を伴っており，LCA は栄養動脈 からの分枝の走行は規則的で，管径は八ケではいたよ うな均一性を保つとしている。本症例は腫湯径が小さ く，血管走行の詳細な評価は困難であったが，明らか な屈曲や蛇行の所見を認めなかった。

LCA と高分化型 HCC は病理組織学的にも鑑別が 困難とされる1)-6). International Working Partyて は，経口避奷薬の服用歴や糖原病などの糖代謝異常の ある症例を LCA と診断し，これらがない場合は高分 化型 HCC PNH を考えるべきとしている ${ }^{1718)}$. 病 理組織学的に LCA は正常の肝細胞に類似した淡明な 腫湯細胞からなり，1〜2層の索状構造で均一な敷石 状配列を示す，細胞や核の異型はなく，門脈域や細胆 管の増生もなく，周囲への浸潤像もみられない(1)5).

本症例の腫瘍は肉眼的に出血や壊死がみられず，病 理組織学的にも淡明な細胞が教石状に増殖し，門脈域 への浸潤もみられず, LCA との鑑別が困難であった。 しかし腫瘍は初回手術時の腫瘍と同様に核胞体比が増 大し, 索状構造が厚く, 細胞密度が高いことから, 脂 肪化を伴った高分化型 HCC と診断した. LCA は正常 肝に発生するといわれるが, 慢性肝炎を背景に発生し, 高分化型 HCC との鑑別が問題となった報告例もあ り, 肝硬変を含めた慢性肝疾患を背景に発生する可能 性も考虑すべきである3゙4．

$\mathrm{HCC}$ 術後の経過観察中に残肝に腫崵を認め, HCC の再発か否かの鑑別に難渋することがある．画像上， 典型的な例では容易に診断ができても，非典型例や腫 瘍径が小さい場合は鑑別が困難であり，より一層の注 意が必要といえよう．高分化型 HCC は濃染しないこ とが多いが, 本症例のように小型であっても LCAに 類似した多血性の画像所見を呈する場合があり，念頭 に置くべきであると考えられた。

\section{結語}

肝細胞腺腫との鑑別を要した多血性高分化型小肝細 胞癌の 1 例を経験したので，文献的考察を加えて報告 した。 


\section{謝辞}

稿を終えるにあたり，病理組䄉学的診断の御指䓕を賜り ました岐阜市民病院臨床检査部の山田鉄也先生に深謝致し ます。

1）萩原 優, 谷一朗, 福島 徹他: 肝細胞癌との 鑑別を要する肝癌類似肝腄浧. 臨外 $58 ： 1219$ 1228,2003

2) 山本雅一, 高崎 健：肝良性腫痬と肝細胞の過形 成結節. 塸外 $56: 877-882,2001$

3）近藤福雄：肝癌の類似病变. 癌の臨 47 :933一 943,2002

4）大森严紀子, 山本雅一，大坪媇人他：大型の高分 化型肝紏胞癌と肝細胞腺腫との鑑別が問題となっ た 1 例. Liver Cancer $9: 60-66,2003$

5) 神代正道：肝細胞腺腫.肝葴 $36: 195-198,1995$

6）神代正道：外科医のための肝腫瘍の病理知識. 幕 内雅敏編, 肝䑏外科の要点と盲点, 文光堂, 東京, 1998, p42-46

7) Ikeda K, Saitoh S, Koida I, et al : Imaging diagnosis of small hepatocellular carcinoma. Hepatology $20: 82-87,1994$

8) Takayasu K, Shima Y, Muramatsu Y, et al: Angiography of small hepatocellular carcinomas: Analysis of 105 resected tumors. AJR $147: 525-529,1986$

9）㖖藤 聡, 池田健次, 小林正宏他：高分化型肝細 胞瘦における濃染像の検討. Liver Cancer 5：
19-24, 1999

10) Kanai T, Hirohashi S, Upton MP, et al : Pathology of small hepatocellular carcinoma. Cancer $60: 810-819,1987$

11）中島収, 神代正道：早期肝癌の病理. 外科治療 $71: 51-58,1994$

12）中山尋之，増田英樹，三宅 洋他：不均一な荟染 像と組織学的分化度が一致した中分化型肝癌を内 包した高分化型肝癌の 1 例. Liver Cancer 5： $51-56,1999$

13）整田昌信、西平友彦，石丸 啓他：PIVKA-II上 昇を伴い右下腹部痛で発症した肝細胞腺腫の 1 例。日瑶外会誌 $63: 1505-1509,2002$

14）高安賢一：肝膤の画像診断一細小肝癌の発見から 治療まで一. 文光堂, 東京, 1991, p147-160

15) Goldstein HM, Neiman HL, Mena E, et al: Angiographic findings in benign liver cell tumors. Radiology $110: 339-343,1974$

16）林 孝行, 関口隆三, 佐竹光夫他：血管造影が决 めてとなった肝細胞腺腫の 1 例一肝細胞腺腫と單 結節型肝細胞癌との血管造影所見の検討一，肝䁍 $37: 256-263,1996$

17）長堀 薏, 永野靖彦, 岩田誠一郎他：肝細胞癌と 鑑別が困難であった肝細胞腺腫の 1 例. 肝贜 $42: 321-326,2001$

18) International Working Party: Terminology of nodular hepatocellular lesions. Hepatology 22 : 983-993, 1995

\title{
A CASE OF HYPERVASCULAR WELL DIFFERENTIATED SMALL HEPATOCELLULAR CARCINOMA WITH DIFFICULTY IN DIFFERENTIATING FROM LIVER CELL ADENOMA
}

\author{
Naomasa YOSHIDA, Hiroshi MATSUO, Takafumi SEKINO, Kenichi SAKAMOTO, \\ Takuya YAMADA, Hirofumi TAKEMURA and Yoshinobu HIROSE* \\ Departments of Advanced Surgery and Pathology*, Gifu University Graduate School of Medicine
}

A 78-year-old man was admitted to the hospital because of a liver tumor detected by abdominal CT. He had a history of undergoing a S5 subsegmentectomy of the liver for hepatocellular carcinoma. The tumor was measuring $1.5 \mathrm{~cm}$ in size in the residual liver $\mathrm{S} 4$ and shown to be a hypervascular lesion by enhanced CT and angiography. Either diagnosis of recurrence of hepatocellular carcinoma or liver cell adenoma was likely for the tumor, because of early demonstration of homogeneous accumulation of contrast material for small well differentiated hepatocellular carcinoma. Accordingly a S4 partial hepatectomy was performed. Macroscopically the tumor was homogeneously white in color with a clear border. Histological examination showed that the tumor consisted of low grade atypical cells proliferating like cobblestone appearance. The tumor was difficult in differentiating from liver cell adenoma and finally diagnosed as well differentiated hepatocellular carcinoma because of its thick trabecular pattern and an increase in nuclear/cell ratio. In conclusion, well differentiated hepatocellular carcinoma can appear as a hypervascular lesion even if it is still small. 